\title{
A Study On Celebrity Endorsed Promotional Video Advertisements With Reference To Jewelers
}

\author{
${ }^{1}$ Pavan Patil \\ ${ }^{1}$ Assistant Professor, Marketing Management, Government of Maharashtra’s Sydenham \\ Institute of Management Studies, Research and Entrepreneurship Education (SIMSREE), \\ Church gate, Mumbai, Maharashtra 400020, India
}

\begin{abstract}
Celebrity endorsers are used highly in advertisements for the promotion of brands to influence buying decision process of customers by marketers. Nowadays all the promotional mediums, whether digital, print, audio, audiovisual and social media, celebrity endorsers are largely seen in advertisements. Promoting brands by endorsing celebrities is much employed by marketers to influence target market, for most of the demographic segments like age, gender, income etc. and kids are also not the exception for it. Marketers of most of the product categories utilize celebrity endorsers in advertisement for promoting their brands. India is known for their attachment with gold and gold ornaments, women's are the real target market for it. Jewelers attempts to influence this target market through advertisements having female celebrity endorsers. This paper tries to analyze the usage of celebrity endorser in the promotional video advertisement with the purpose to contribute in optimizing the usage of celebrity endorser in such advertisements. The study focuses on conveniently selected celebrity endorsed promotional video advertisements of jewelers. It is found from the study that the celebrity endorsers are less utilized in the promotional video advertisements and there is more scope to optimize the usage of celebrity endorsers in promotional video advertisements.
\end{abstract}

Keywords: Advertisement, Celebrity, Endorser, Jewelers, Video

\section{Introduction}

Celebrity endorsers are used highly in advertisements for the promotion of brands to influence buying decision process of customers by marketers. Nowadays all the promotional mediums, whether digital, print, audio, audiovisual and social media, celebrity endorsers are largely seen in advertisements. Promoting brands by endorsing celebrities is much employed by marketers to influence target market, for most of the demographic segments like age, gender, income etc. and kids are also not the exception for it. Marketers of most of the product categories utilize celebrity endorsers in advertisement for promoting their brands. India is known for their attachment with gold and gold ornaments, women's are the real target market for it. Jewelers attempts to influence this target market through advertisements having female celebrity endorsers. McCracken (1989) suggested following four different modes of celebrity endorsers namely, Explicit mode (the celebrity overtly declares the endorsement of product), Implicit mode (physical / verbal communication is used by celebrity for the product), Imperative mode (the celebrity suggests the viewers to use the product), Co-present mode (the celebrity only appears with the product) ${ }^{[11]}$. So it becomes important to know how celebrity endorsers can be best optimised for promotional purpose and also it becomes interesting to analyse in which mode mentioned above celebrity endorsers are portrayed in promotional video advertisement and how they can be portrayed so as to make them more effective.

\section{Objectives:}

The main objective is to study the mode and usage of celebrity endorser in promotional video advertisement of jewelers.

\section{Purpose of Research:}

The paper tries to study the celebrity endorsed promotional video advertisements and attempts to analyze the portrayal and usage of celebrity endorser in the advertisements, so as to contribute in optimizing the usage of celebrity endorser in advertisements. 


\section{Review of Literature}

(Jaysingha \& Shivani, 2018) states celebrity endorsement as effective advertising method having great potential to convey message to the customers and consumers. They further states that the role played by the celebrity in the advertisement directly impacts on the purchase decision made by the consumers. They mention that whatever the messages they pass through the celebrity endorsement directly and indirectly goes to the customers ${ }^{[12]}$. (JainV.et.al 2010) in their content analysis revealed that most of the ads using celebrity endorsers were of the implicit (suggestive) nature which may imply that a popular celebrity in the Implicit Mode could be used effectively by a brand, a very important determinant of which may be culture. They also found that $64 \%$ of Indian TVC portrayed celebrity endorsers in implicit mode for different product categories ${ }^{[11]}$. (Silburyte, 2009) states in their work on how celebrities can be used in advertising to the best advantage about gender of celebrity, congruence between celebrity endorser and target consumer, credibility, expertise, attractiveness and popularity of celebrity endorser and also suggest multiple celebrity endorsement for enhancing effectiveness of advertising campaign ${ }^{[13]}$.

\section{Analysis of identification of celebrity endorser portrayal mode and usage}

5.1 Jweller-1, Mode and duration of Portrayal of celebrity endorser in the promotional video advertisement - Co-present, Duration of copresent mode out of total duration - $10 \%{ }^{[1]}$.

5.2 Jweller-2, Mode and duration of Portrayal of celebrity endorser in the promotional video advertisement - Co-present, Duration of copresent mode out of total duration $-30 \%{ }^{[2]}$.

5.3 Jweller-3, Mode and duration of Portrayal of celebrity endorser in the promotional video advertisement - Co-present, Duration of copresent mode out of total duration $-80 \%{ }^{[3]}$.

5.4 Jweller-4, Mode and duration of Portrayal of celebrity endorser in the promotional video advertisement - Co-present, Duration of copresent mode out of total duration $-8.10 \%{ }^{[4]}$.

5.5 Jweller-5, Mode and duration of Portrayal of celebrity endorser in the promotional video advertisement - Co-present, Duration of copresent mode out of total duration $-1.66 \%{ }^{[5]}$.

5.6 Jweller-6, Mode and duration of Portrayal of celebrity endorser in the promotional video advertisement - Co-present, Duration of copresent mode out of total duration $-1.66 \%{ }^{[6]}$.
5.7 Jweller-7, Mode and duration of Portrayal of celebrity endorser in the promotional video advertisement - Implicit and Co-present, Duration of co-present and implicit mode out of total duration $-20 \%$ and $20 \%$ respectively ${ }^{[7]}$.

5.8 Jweller-8, Mode and duration of Portrayal of celebrity endorser in the promotional video advertisement - Co-present, Duration of copresent mode out of total duration - $0 \%{ }^{[8]}$.

5.9 Jweller-9, Mode and duration of Portrayal of celebrity endorser in the promotional video advertisement - Implicit, Duration of implicit mode out of total duration $-3.38 \%{ }^{[9]}$.

5.10 Jweller-10, Mode and duration of Portrayal of celebrity endorser in the promotional video advertisement - Co-present, Duration of copresent mode out of total duration $-9.09 \%{ }^{[10]}$.

It can be analysed that the celebrity endorsers are majorly preferred to be utilized in co-present mode by jewellery marketers and they are less utilized in the promotional video advertisements concerning the duration of mode.

\section{Findings}

It is found that $80 \%$ of jewellers have used celebrity endorsers in co-present mode, $10 \%$ of jewellers have used celebrity endorsers in implicit mode, $10 \%$ of jewellers have used celebrity endorsers in both implicit mode and co-present mode and none of the jeweller has utilized celebrity endorser in explicit mode and imperative mode. Out of the total duration of promotional video advertisement, the duration of co-present mode of celebrity portrayal ranges from minimum $0-1.66 \%$ to maximum $80 \%$.

\section{Methodology}

Data is obtained for the said work through internet search, concerned websites and journal research papers. Secondary sources are used for work and analysis is done qualitatively. Study focused on conveniently shortlisted promotional video advertisements of jewellers for analysing.

\section{Limitations:}

It is based on conveniently shortlisted celebrity endorsed promotional video advertisements of jewelers only. The comparative effectiveness of each mode of celebrity endorser portrayal is not studied in the work. The measurement and identification of duration and mode is done by manual observation not by technical method. The said work is not conclusive in nature; also it is based on secondary 
sources instead of primary. The approach is exploratory in manner.

\section{Further research areas:}

Comparative effectiveness amongst each mode of celebrity endorser portrayal can be researched, so as to know and employ most effective mode. The said study can be extended to other product categories promotional video advertisements. Also a customer oriented primary study could be thought over.

\section{Implication:}

The practitioners can get an idea from the said study about thinking and acting about portraying celebrities in different modes in promotional video advertisements and also creating and inserting more opportunities for increasing the duration of concerned mode of celebrity endorser's portrayal. The work is helpful for jewellers and other practitioners for optimizing and selecting mode of celebrity endorser portrayal in promotional video advertisements and also in enriching the impact of celebrity endorsement on customers.

\section{Conclusion:}

It could be mentioned that co-present mode is preferred mode of celebrity endorser portrayal in promotional video advertisement by jewelers. The duration of co-present mode of celebrity portrayal in promotional video advertisement is less in overall duration. It could also be stated that there is a scope and opportunity to utilize and improve promotion of brands through celebrity endorser by optimizing celebrity portrayal mode and its duration.

\section{References}

[1] (n.d.). Retrieved from https://www. youtube.com: https://www.youtube.com/watch?v=g4NXU N42fuI\&feature=youtu.be

[2] (n.d.). Retrieved from https://www. youtube.com:
https://www.youtube.com/watch?v=uOqLd mDT6Cc

[3] (n.d.). Retrieved from https://www. youtube.com:

https://www.youtube.com/watch?v=ZXDhg 2 wjJbk\&feature $=$ youtu.be

[4] (n.d.). Retrieved from https://www. youtube.com:

https://www.youtube.com/watch?v=Q5RGs SnKnqQ

[5] (n.d.). Retrieved from https://www. youtube.com:

https://www.youtube.com/watch?v=9yj2jx KcCRY

[6] (n.d.). Retrieved from https://www. youtube.com:

https://www.youtube.com/watch?v=E1 vdH XFfLuU

[7] (n.d.). Retrieved from https://www .youtube.com:

a. https://www. youtube.com/watch?v=fu9N6zLo9 T0

[8] (n.d.). Retrieved from https://www. youtube.com:

https://www.youtube.com/watch?v=p88iXq $\mathrm{xWvHQ}$

[9] (n.d.). Retrieved from https://www. youtube.com:

https://www.youtube.com/watch?v=hymYl ATQqGY

[10](n.d.). Retrieved from https://www. youtube.com:

https://www.youtube.com/watch?v=KisKY olQ--o

[11]Jain, V., Roy, S., Daswani , A., \& Sudha, M. (2010). How Celebrities are used in Indian Television Commercials. Vikalpa, 45-52.

[12] Jaysingha, S. M., \& Shivani, S. (2018). Critical Discourse Analysis of Sinhala Cultural Identity in Celebrity Endorsement in Newspaper Advertisements. International Journal of Business Marketing and Management, 1-16.

[13] Sliburyte, L. (2009). How Celebrities Can Be Used In Advertising to the Best Advantage? World Academy of Science, Engineering and Technology, 934-939. 